\title{
IZRADA SMJERNICA ZA IZGRADNJU \\ FONDA U HIBRIDNIM KNJIŽNICAMA - ISKUSTVA \\ SVEUČILIŠNE KNJIŽNICE RIJEKA
}

\author{
CREATING LIBRARY COLLECTION DEVELOPMENT \\ GUIDELINES IN HYBRID LIBRARIES - THE UNIVERSITY \\ LIBRARY RIJEKA EXPERIENCES
}

Sanja Kosić
skosic@svkri.hr
Sanja Heberling Dragičević
shdragicevic@svkri.hr
Sveučilišna knjižnica Rijeka

UDK / UDC 021/025:[027.7:004](497.5 Rijeka)

Stručni rad / Professional paper

Primljeno / Received: 28.8.2017.

Prihvaćeno / Accepted: 3.11.2017.

\section{Sažetak}

Cilj: Cilj je ovoga rada istaknuti temeljne probleme izrade smjernica u knjižničnom poslovanju, njihov značaj, elemente koje trebaju sadržavati te navedeno prezentirati na primjeru izrade smjernica Sveučilišne knjižnice Rijeka (SVKRI).

Pristup/metodologija/dizajn: U radu se iznose definicije smjernica za izgradnju fonda, naglašava njihov značaj, nužnost izrade i nužni elementi samog dokumenta. Prezentiraju se rezultati pretraživanja mrežnih stranica sveučilišnih knjižnica provedenog tijekom prosinca 2016., a potom se iznose temeljne postavke smjernica koje se izrađuju u Sveučilišnoj knjižnici Rijeka.

Rezultati: U izradi smjernica SVKRI se služi postojećim teorijskim spoznajama i praktičnim primjerima sveučilišnih knjižnica zapadnoeuropskih zemalja i SAD-a.

Vjesnik bibliotekara Hrvatske 60, 4(2017), 161-189

ISSN 0507-1925

(C) VBH 2017. 
Praktična primjena: Izneseni teoretski podaci i primjeri iz SVKRI-a mogu poslužiti kao pomoć knjižnicama koje se odluče na izradu vlastitih smjernica za izgradnju fonda.

Originalnost/vrijednost: Iz rezultata pretraživanja vidljivo je da izrada smjernica za izgradnju fonda nije raširena u hrvatskim knjižnicama. Autorice smatraju važnim izraditi i javno objaviti takav dokument, koji treba biti jedan od temelja knjižničnog poslovanja. Prezentirane teorijske spoznaje, kao i predviđeni elementi smjernica SVKRI-a, prilog su poticanju knjižnica na njihovu izradu, posebno u suvremenom promjenjivom okruženju u kojem knjižnice djeluju.

Ključne riječi: izgradnja knjižničnog fonda, smjernice za izgradnju fonda, Sveučilišna knjižnica Rijeka, upravljanje knjižničnim fondom

\begin{abstract}
Purpose. The purpose of this paper is to emphasize the difficulties in the process of creatig the library development guidelines document, its importance and the elements it should include, and then present all these factors on the example of creating the collection development guidelines in the University Library Rijeka.
\end{abstract}

Approach/Methodology/Design. The paper presents several definitions of collection development guidelines, emphasizes their signifacance and the necessity of creating this document for libraries, as well as the elements it should contain. The paper presents the results of the research conducted by browsing the web sites of six Croatian university libraries in December 2016, and then discusses the fundamental principles of collection development guidelines in the University Library Rijeka.

Findings. In the process of creating the guidelines for the University Library Rijeka, the selected theoretical findings as well as some examples of good practices in Western European and American university libraries were used.

Practical implications. The presented data and the examples may serve as a model to other libraries that decide to create and implement their own library collection development guidelines.

Originality/Value. The research results have shown that the practice of creating the collection development guidelines is still not widely accepted in Croatian libraries. The authors point out the importance of creating this document and making it public for libraries, emphasizing that it should be one of the fundamental documents in library business.

Keywords: library collection development, library collection development policy, library collection management, The University Library Rijeka 


\section{Uvod}

Knjižnica, kao i svaki drugi poslovni subjekt, mora osigurati određene uvjete kako bi mogla ispunjavati zadaće određene svojom misijom. Mora osigurati prostor, knjižnični fond, osoblje i adekvatne izvore financijskih sredstava. Knjižnični je fond međutim njezin temeljni resurs na kojem se temelji cijelo poslovanje. Pritom pojam knjižničnog fonda valja shvatiti u širem smislu, ne kao tradicionalni fond $\mathrm{u}$ isključivo materijalnom obliku, već fond koji se sastoji od građe, tj. sadržaja koji je dostupan na različitim nositeljima, u raznim oblicima, odnosno kojem je moguće pristupiti na daljinu.

Promjena koju je u posljednjim desetljećima doživio knjižnični fond, a koja je izravno potaknuta razvojem i implementacijom informacijsko-komunikacijske tehnologije u sva područja ljudskog života, ono je što razlikuje tradicionalnu knjižnicu od hibridne, odnosno digitalne knjižnice. Pojam hibridne knjižnice odnosi se na knjižnice koje bi trebale istovremeno omogućiti korištenje tradicionalne tiskane te novije elektroničke građe. Njihov je osnovni cilj sadržaj učiniti dostupnim korisniku pomoću raznih informacijskih usluga, i to bez obzira na medij koji je nositelj tog sadržaja. ${ }^{1}$ Ove knjižnice predstavljaju prijelazni oblik od tradicionalne prema digitalnoj knjižnici, ali je jezgra njihova poslovanja i dalje knjižnični fond. Razlika je u tome što se u hibridnim knjižnicama promijenio sam fond, pa se više ne govori samo o dostupnosti materijalne jedinice građe unutar fizičkog prostora knjižnice, već prije svega o pristupu sadržaju bez obzira na vrijeme, mjesto ili nositelje sadržaja.

\section{Izgradnja i upravljanje knjižničnim fondom}

Knjižnični fond ni u jednoj knjižnici ne nastaje sam od sebe, već je rezultat niza aktivnosti stručnog osoblja u postupcima izgradnje fonda. Posljednjih se desetljeća, posebno u američkoj knjižničarskoj teoriji i praksi, govori o postupcima izgradnje i upravljanja knjižničnim fondom. Ovisno o pojedinom autoru, ti se postupci promatraju kao odvojeni ili kao dvije faze istog postupka. No bez obzira na to kako se promatraju, jasno je da je riječ o postupcima koji su jedan o drugome ovisni, odnosno dio su ciklusa izgradnje knjižničnog fonda.

Sam proces izgradnje fonda (engl. collection development, collection building) E. Kodrič-Dačić definira kao planirani proces prikupljanja građe, čiji je cilj u nekom budućem razdoblju oblikovati koherentnu i relevantnu zbirku. ${ }^{2}$ Ista autorica pod pojmom upravljanje zbirkama (engl. collection management) podra-

1 Živković, D. Knjižnice na putu od poslanja do strategije: osvrt na hrvatske prilike. // Vjesnik bibliotekara Hrvatske 58, 1-2(2015), str. 3.

2 Kodrič-Dačić, E. Uvod v izgradnjo knjižničnih zbirk. // Knjižnica 51, 1(2007), str. 92. [citirano: 2017-01-31]. Dostupno na: http://revija-knjiznica.zbds-zveza.si/Izvodi/K0701/kodric1.pdf. 
zumijeva sve postupke izgradnje zbirki, ali i njihovu organizaciju i održavanje. Američka autorica P. Johnson procese selekcije i nabave građe drži izgradnjom, a sve procese koji se događaju nakon što je građa jednom uvrštena u fond procesima upravljanja fondom. ${ }^{3}$

Proces izgradnje fonda započinje analizom postojećeg stanja te vanjskih i unutarnjih faktora koji na izgradnju fonda utječu ili bi na nju mogli utjecati. Za sveučilišnu knjižnicu to znači analizirati vlastitu misiju i viziju, provjeriti je li ona usklađena s vizijom i misijom sustava u kojem djeluje (npr. usklađenost misije knjižnice s misijom sveučilišta), analizirati vlastitu korisničku zajednicu i unutarnje faktore knjižnice (prostor, opremu, kadrove).

$\mathrm{Na}$ osnovi provedene analize potrebno je izraditi pisane smjernice za izgradnju fonda koje bi trebale biti temeljni dokument koji svim djelatnicima služi kao vodič u radu s fondom. Johnson je knjižnice bez smjernica za izgradnju fonda usporedila s tvrtkama bez poslovnog plana. ${ }^{4}$ Nepostojanje plana dovodi do toga da knjižničari koji bi trebali izgrađivati fond nemaju jasnu sliku o tome kako taj fond treba izgledati i koje ciljeve treba ispuniti, te su samim time onemogućeni da cijeli postupak odrade na najbolji mogući način i s najboljim mogućim rezultatima za sustav u cjelini. Rezultat izgradnje knjižničnog fonda bez plana obično su uzaludno potrošeno vrijeme i neučinkovito utrošena financijska sredstva. Posebno je to problematično u današnje vrijeme, kada su u knjižnicama raspoloživa financijska sredstva nedostatna i najčešće pokazuju tendenciju smanjenja.

Jednom kada je proces selekcije i nabave građe dovršen, odnosno kada je građa uvrštena u knjižnični fond, započinje proces upravljanja fondom. U praksi, odluke i postupci u upravljanju fondom potaknuti su najčešće njegovim trenutnim stanjem, budžetom knjižnice ili, nerijetko, prostornim ograničenjima za fizičke zbirke. Upravljanje fondom podrazumijeva sljedeće aktivnosti: pročišćavanje, otpis, preseljenje u drugo spremište (koje može biti i dislocirano), otkazivanje pretplata, prijelaz na elektroničke inačice i zaštitu fonda od prirodnih katastrofa i nepogoda koje je uzrokovao čovjek. ${ }^{5}$ Postojanje smjernica u kojima su jasno navedeni kriteriji i postupci može znatno olakšati provođenje svakog od spomenutih postupaka.

\section{Smjernice za izgradnju fonda - pojam, značaj, svrha i sadržaj}

Smjernice za izgradnju fonda moguće je definirati kao formulaciju ili općenitu izjavu o namjeri koja pomaže prevesti ciljeve programa u realizaciju, dajući

\footnotetext{
3 Johnson, P. Fundamentals of collection development and management. 2nd ed. Chicago : American Library Association, 2009. Str. 151.

4 Isto, str. 72.

5 Isto, str. 151.
} 
pritom konkretne stručne upute za donošenje odluka i njihovu implementaciju. ${ }^{6}$ Pisane smjernice osiguravaju okvir unutar kojeg knjižničari obavljaju svoje zadatke. One su osnova prema kojoj se kroz vrijeme prati napredak u području izgradnje i upravljanja fondom i temelj za ocjenu uspješnosti knjižničara koji se tim poslovima bave, ali i misije knjižnice. U ovom se trenutku u Hrvatskoj o smjernicama za izgradnju nedovoljno piše. Najčešće ih se spominje u radovima iz područja izgradnje fonda. O izgradnji fonda pisala je Z. Majstorović u doktorskoj disertaciji Razvoj zbirki u sveučilišnom knjižničnom sustavu primjenom Conspectus modela ${ }^{7}$ te u suradnji s K. Ivić u radu Izgradnja zbirki u sveučilišsnom knjižničnom sustavu : model. ${ }^{8} \mathrm{O}$ nabavi knjižnične građe u visokoškolskim knjižnicama pisala je T. Krajna ${ }^{9}$, a o daru kao načinu izgradnje zbirki u hrvatskim narodnim knjižnicama I. Hebrang Grgić. ${ }^{10}$ No izvjesno je da će biti više rasprava o samim smjernicama ukoliko se usvoji Prijedlog Zakona o knjižnicama i knjižničnoj djelatnosti. U Prijedlogu Zakona u članku 3., stavku 1. predviđa se obveza svake knjižnice da donese pisane smjernice za nabavu, kriterije za vrednovanje fonda te pravila i mjere za čuvanje i zaštitu knjižnične građe. ${ }^{11}$

IFLA-ine Upute za izradbu smjernica za izgradnju knjižnične zbirke primjenom modela Conspectus naglašavaju da je zadaća knjižnice odabir, održavanje i omogućavanje pristupa značajnim i reprezentativnim informacijskim izvorima, a smjernice za izgradnju opisuju zbirke kao okvir i skup mjerila unutar kojih djelatnici rade, a korisnici znaju što mogu očekivati od zbirke. ${ }^{12}$ Smjernice opisuju tekuću zbirku i potiču djelatnike da kontinuirano razmatraju misiju knjižnice. Pomagalo su u pitanjima financiranja, a služe i kao komunikacijski kanal unutar knjižnice te iz knjižnice prema van. IFLA pritom navodi četiri temeljna razloga za izradu pisanih smjernica: odabir, planiranje, odnosi s javnošću i šire okruženje

\footnotetext{
6 Sanchez Vignau, B. S.; G. Meneses. Collection development policies in university libraries : a space for reflection. // Collection Building 24, 1(2005), str.37. doi: https://doi. org/10.1108/01604950510576119.

7 Majstorović, Zagorka. Razvoj Zbirki u sveučilišnom knjižničnom sustavu primjenom Conspectus modela : doktorska disertacija. Zagreb : Z. Majstorović, 2009. Str. 60-87.

8 Majstorović, Zagorka; Ivić, Kata. Izgradnja zbirki u sveučilišnom knjižničnom sustavu : model. // Vjesnik bibliotekara Hrvatske 54, 3(2011), str. 51-53.

9 Krajna, T. Nabava knjižnične građe u visokoškolskim knjižnicama. // Vjesnik bibliotekara hrvatske 54, 3(2011), str. 24-26.

10 Hebrang Grgić, I. Dar kao način izgradnje zbirki u hrvatskim narodnim knjižnicama. // Vjesnik bibliotekara Hrvatske 54, 3(2011), str. 100-105.

11 Prijedlog Zakona o knjižnicama i knjižničnoj djelatnosti. Srpanj 2014. [citirano: 2017-02-01]. Dostupno na: http://www.hkdrustvo.hr/clanovi/alib/datoteke/20140905-Prijedlog_zakona_o_ knjiznicama_i_knjiznicnoj_djelatnosti_za_strucnu_raspravu(1).doc.

12 Darovi za zbirke : smjernice za knjižnice. Upute za izradbu smjernica za izgradnju knjižnične zbirke primjenom modela Conspectus.; Međunarodna posudba i dostava dokumenata : načela i smjernice za postupanje; Model nacionalnog pravilnika za međuknjižničnu posudbu. Zagreb : Hrvatsko knjižničarsko društvo, 2010. Str. 33.
} 
(smjernice mogu biti temelj za širu suradnju i zajedničko korištenje izvora, bilo zavičajno, područno, na državnoj ili međunarodnoj razini).

R. D. Stueart i B. B. Moran izdvajaju nekoliko temeljnih obilježja kvalitetnih smjernica: ${ }^{13}$

- konzistentnost

- fleksibilnost, odnosno mogućnost njihove promjene i/ili nadopune kada se za to ukaže potreba

- služe kao vodič, a ne kruto pravilo

- u pisanom su obliku.

Nije moguće izraditi smjernice koje će nepromijenjene dugoročno ispunjavati svoju svrhu. One definiraju okvir, daju kriterije, usmjeravaju, ali nisu strogi vodič za nabavu određenog naslova. Bez obzira na dubinu i kvalitetu smjernica, stručna je ocjena knjižničnog osoblja u postupcima izgradnje i upravljanja fondom neizbježna.

Kao dvije temeljne svrhe smjernica P. Johnson istaknula je informiranje i zaštitu. Pod svrhom informiranja podrazumijeva se informiranje o misiji knjižnice, trenutnom stanju i sadržaju fonda te ciljevima u budućnosti. Definiranjem željenog budućeg stanja postavlja se podloga za benchmarking procjenu rezultata vlastitih aktivnosti, odnosno uspoređivanje sadašnjeg i nekog budućeg stanja, a time i za mogućnost procjene uspješnosti izgradnje i upravljanja fondom. Svrha zaštite ogleda se u zaštiti od pritisaka izvana. Jasne smjernice štite knjižnicu od nerazumnih zahtjeva korisnika, osnivača, financijera i zainteresirane javnosti, i to tako što na jasan način prezentiraju misiju knjižnice i način na koji knjižnični fond tomu pridonosi.

U procesu izrade smjernica potrebno je voditi se određenim teorijskim postavkama $\mathrm{i}$ iskustvima usporedivih knjižnica. Ipak, u svakom je trenutku potrebno imati na umu svrhu izrade smjernica, kao i populaciju kojoj su one namijenjene. Stoga je vrlo teško odrediti obvezne elemente koje pojedine smjernice moraju sadržavati. F. W. Hoffmann i R. J. Wood identificirali su niz elemenata koje bi smjernice za izgradnju fonda trebale sadržavati: izjava o svrsi, izjava o razlozima izrade smjernica, odgovornost za izradu, misija i ciljevi, ciljna publika, financiranje, kriteriji procjene, formati, službene publikacije, specijalne zbirke, dijeljenje resursa, usluge, autorska prava, intelektualne slobode, nabava, darovi, razmjena, održavanje fonda, pročišćavanje, procjena zbirke i revizija smjernica. ${ }^{14}$ Koji će

\footnotetext{
13 Stueart, Robert D.; Moran, Barbara B. Library and information center management. 7th ed. Westport, Conn. : Libraries Unlimited, 2007. Citirano prema: Darovi. Nav. dj., str. 33.

14 Hoffmann, F.W.; R. J. Wood. Library collection development policies: academic, public, and special libraries. Lanham : Scarecrow Press, 2005. Citirano prema: Johnson, P. Nav. dj., str. 77
} 
se od tih elemenata naći u konkretnim dokumentima, ovisi o stručnoj procjeni osoblja koje ih izrađuje, misiji knjižnice i svrsi izrade smjernica.

Brojni su radovi koji istražuju pojam i kontekst hibridnih knjižnica, odnosno načina na koji su se tradicionalne knjižnice prilagodile pojavi elektroničke građe. R. F. Guy analizirao je proces prilagodbe Nacionalne knjižnice Škotske i njezinu transformaciju u hibridnu knjižnicu. Navodi problem pohrane elektroničke građe koji je aktualan i danas, kako u nas tako i u svijetu. Ističe da je izgradnja hibridne knjižnice uvjetovana postojanjem niza preduvjeta: tehničkom infrastrukturom, programskom podrškom te omogućavanjem i kontrolom pristupa sadržaju. ${ }^{15}$ T. Horava i M. Levine-Clark proveli su istraživanje o trenutnim trendovima u izgradnji knjižničnih fondova i pripadajućim politikama u SAD-u. Njihovo je istraživanje pokazalo da knjižnice sredstva namijenjena izgradnji fonda nerijetko preusmjeravaju u druge svrhe te da velik broj knjižnica u većoj ili manjoj mjeri eksperimentira s nabavom građe koja se temelji na zahtjevima korisnika. ${ }^{16}$ Većina knjižnica podupire inicijative otvorenog pristupa, a međusobno prakticiraju različite načine dokazivanja svoje vrijednosti osnivačima, među kojima ipak prednjači kvantitativni pristup, odnosno prezentiranje podataka o korištenosti sadržaja, citatne analize, analize troška po određenoj jedinici i sl. Od kvalitativnih pristupa u pravilu se radi o isticanju uspjeha studenata, razvoju novih usluga i povećanju zadovoljstva korisnika općenito. Sve navedene informacije mogu pomoći u oblikovanju smjernica određene knjižnice.

\section{Knjižnični fond Sveučilišne knjižnice Rijeka}

Cjelokupan fond Sveučilišne knjižnice Rijeka izgrađivan je tijekom 390 godina povijesti knjižnice. Današnji se fond temelji na građi knjižnice Isusovačkog kolegija koji je 1627. u Rijeci osnovao Isusovački red. Temeljni dokument o ustroju tog kolegija odredio je i osnivanje knjižnice za potrebe profesora i studenata kolegija. Knjige te knjižnice temelj su fonda Sveučilišne knjižnice Rijeka. ${ }^{17}$

Godine 1948. osnovana je Naučna biblioteka u Rijeci, koja je godinu kasnije počela zaprimati po jedan obvezni primjerak knjižnične građe tiskane u Hrvatskoj. Godine 1995. Naučna biblioteka mijenja naziv u Sveučilišna knjižnica Rijeka, a njezinim osnivačem postaje Sveučilište u Rijeci, čija je i danas sastavnica.

Kao rezultat višestoljetnog razvoja, danas Sveučilišna knjižnica Rijeka ima prilično složen sustav zbirki i podzbirki. Veći dio fonda unesen je u računalni

15 Guy, R. F. Developing the hybrid library: progress to date in the National Library of Scotland. // The Electronic Library 18, 1(2000), str. 48. DOI: https://doi.org/10.1108/02640470010320452.

16 Horava, T.; M. Levine-Clark. Current trends in collection development practicies and policies. // Collection Building 35, 4(2016), str. 97. DOI: https://doi.org/10.1108/CB-09-2016-0025.

17 Sveučilišna knjižnica Rijeka, Povijest. [citirano: 2017-01-15]. Dostupno na: http://www.svkri.uniri.hr/index.php/o-nama/povijest. 
katalog te je kroz njega pretraživ, no dio fonda, posebno onog baštinskog, još se unosi. Trenutno se fond dijeli na tri velike zbirke: Zbirku stare i rijetke građe, Zavičajnu zbirku Adriatica i Znanstvenu zbirku.

Zbirka stare i rijetke građe sastoji se od dva osnovna dijela: Bibliotece civice i Povijesne zbirke koja se sastoji od oko 40000 jedinica pristiglih u knjižnicu nakon 2. svjetskog rata, a nastalih ili korištenih na riječkom području tijekom proteklih stoljeća, zaključno s 1947. Njezin je najvredniji dio Rara koja obuhvaća inozemnu građu izdanu do 1830., odnosno hrvatsku građu izdanu do 1850. Zavičajna zbirka Adriatica također je podijeljena na podzbirke: Sveučilišni repozitorij i Opći dio zbirke, a obuhvaća građu koja je nastala na području zavičaja, čiji su autori s tog područja, odnosno čiji se sadržaj odnosi na to područje. Opći fond (Znanstvena zbirka) sadrži opći dio Nacionalne zbirke te posudbeni dio fonda. Dio fonda koji je knjižnica zaprimila u imovinu ${ }^{18}$ zaključno s polovicom svibnja 1969. kulturno je dobro i kao takav zahtijeva poseban tretman i pažnju.

Takav složen sustav zbirki i podzbirki više ne odgovara ni potrebama knjižnice ni korisnika. Razvojem SVKRI-a iz tradicionalne u hibridnu knjižnicu, kao i promjenama u potrebama korisnika, javila se potreba za preustrojem fizičkih zbirki knjižnice i definiranjem okvira u kojem će Knjižnica razvijati svoje digitalne zbirke. Fizičke je zbirke nužno ustrojiti na način da već iz njihova opisa bude vidljivo kakvu građu sadrže, komu su namijenjene te koji su uvjeti korištenja građe. U tom procesu smjernice za izgradnju fonda trebaju imati glavnu ulogu.

\section{Izrada Smjernica za izgradnju fonda Sveučilišne knjižnice Rijeka}

Postupak izrade smjernica u Sveučilišnoj knjižnici započeo je tijekom 2016. U izradu je uključen veći broj djelatnika knjižnice. Započelo se od definirane misije i vizije SVKRI-a, a nastavlja se proučavanjem zakonodavnog i institucijskog okvira te primjera dobre prakse. Na temelju tih saznanja i slike fonda koji se želi u budućnosti pristupilo se izradi temeljnih postavki, odnosno zahtjeva koje je kroz smjernice potrebno ispuniti.

\subsection{Poslanje}

Poslanje Sveučilišne knjižnice Rijeka jest čuvati baštinske fondove te izgrađivati nove izvore i usluge primjerene potrebama pripadnika Sveučilišta u Rijeci, zajednice i gospodarstva. ${ }^{19}$ Knjižnica teži osigurati korištenje knjižničnih izvora s ciljem dodavanja vrijednosti kvaliteti učenja te obrazovnog, znanstvenog, struč-

\footnotetext{
18 Sva građa koja je u inventarne knjige SVKRI-a upisana zaključno s 15. 5. 1969. i koja je rješenjem nadležnog Konzervatorskog ureda proglašena kulturnim dobrom.

19 Sveučilišna knjižnica Rijeka. Vizija i misija. [citirano: 2017-01-17].

${ }^{\mathrm{Do}}$ stupno na: http://www.svkri.uniri.hr/index.php/o-nama/vizija-i-misija.
} 
nog, umjetničkog i svakog drugog rada. Postojeći ustroj materijalnog fonda ne predstavlja dobar temelj za ispunjavanje misije knjižnice. Pored toga, da bi knjižnica uspješno potpomagala procese učenja te obrazovnog, znanstvenog, stručnog i umjetničkog rada, mora uvrstiti u svoj fond sadržaje na drugim nositeljima, odnosno osigurati pristup potrebnim sadržajima na daljinu.

Iz navedenog je proizašla potreba izrade i primjene sveobuhvatnih smjernica za izgradnju i upravljanje fondom, koje će obuhvatiti postojeći materijalni fond te ga ustrojiti na način da bude više u službi misije knjižnice, ali i koje će dati okvir za izgradnju digitalnih zbirki, bilo digitalizacijom građe iz vlastitog fonda ili osiguravanjem pristupa građi koja je korisničkoj populaciji potrebna, a nije vlasništvo knjižnice.

\subsection{Zakonodavni i institucionalni okvir}

Izradi strateškog dokumenta poput smjernica valjalo je pristupiti vrlo ozbiljno. Prije svega, potrebno je proučiti zakonsku regulativu koju knjižnica u svom poslovanju mora poštovati jer nijedan dokument ne smije biti u suprotnosti s pozitivnim zakonskim i podzakonskim propisima. Tako se u prvom koraku proučavaju odredbe Zakona o knjižnicama, Zakona o zaštiti i očuvanju kulturnih dobara, Zakona o autorskom pravu i srodnim pravima, Zakona o pravu na pristup informacijama, Zakona o arhivskom gradivu i arhivima, Pravilnika o reviziji i otpisu, Pravilnika o zaštiti građe i drugih propisa koji se izravno ili neizravno dotiču poslovanja knjižnice.

Pored zakonskih propisa, knjižnica se mora upoznati sa svim ostalim elementima koji bi mogli utjecati na izgradnju i upravljanje fondom. Prije svega, to se odnosi na nacionalne politike prema knjižnicama i knjizi, modele financiranja nabave građe, stav osnivača prema samoj knjižnici i njezinu značenju za korisničku zajednicu te spremnost za podupiranje rada knjižnice. U konkretnom primjeru SVKRI mora pratiti sve aktivnosti Ministarstva znanosti i obrazovanja, a s obzirom na veliku i važnu baštinsku zbirku te zaštićeno kulturno dobro i aktivnosti Ministarstva kulture. Svoju misiju mora uskladiti s misijom Sveučilišta, a u komunikaciji s osnivačem nastojati osigurati stabilno financiranje i potporu radu knjižnice.

\subsection{Primjeri dobre prakse}

Drugi korak u pripremi za izradu smjernica jest proučavanje prakse srodnih knjižnica. Valja proučiti primjere u zemlji u sličnim knjižnicama, a potom i izvan njezinih granica. Pretraživanjem mrežnih stranica šest sveučilišnih knjižnica u Hrvatskoj (Pula, Zadar, Split, Osijek, Zagreb, Dubrovnik) utvrđeno je da one nemaju javno objavljene smjernice za izgradnju fonda. Izuzetak je u određenoj mjeri Gradska i sveučilišna knjižnica Osijek (GISKO) koja je objavila Upute za 
nabavu. ${ }^{20}$ No GISKO, za razliku od SVKRI-a, ima drukčiju misiju, s obzirom na to da se radi o knjižnici koja je i narodna i sveučilišna knjižnica. U spomenutim je uputama naglasak stavljen upravo na njezinu funkciju narodne knjižnice. Sličan

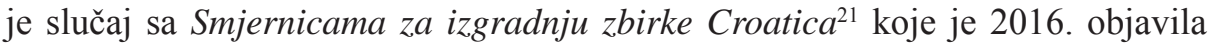
Nacionalna i sveučilišna knjižnica. Iako se radi o sveobuhvatnom dokumentu koji sadrži sve potrebne kriterije za izgradnju te zbirke, kao i navode o mogućnostima korištenja, formatima i sl., radi se o zbirci koja predstavlja nacionalnu baštinu i pripada onom dijelu poslovanja NSK-a koji se odnosi na njezinu nacionalnu, a ne sveučilišnu funkciju. Ipak, Smjernice za izgradnju zbirke Croatica pomoć su pri oblikovanju Nacionalne zbirke u SVKRI-u.

Nakon pregleda mrežnih stranica sveučilišnih knjižnica u Hrvatskoj, pregledane su i stranice sveučilišnih knjižnica susjednih zemalja: Slovenije, Bosne i Hercegovine, Srbije i Crne Gore. U identificiranju pojedinih sveučilišnih knjižnica koristilo se stranicama nacionalnih ministarstava znanosti na kojima je naveden popis sveučilišta koja djeluju u pojedinoj državi.

U Sloveniji djeluju četiri sveučilišne knjižnice (Narodna in univerzitetna knjižnica Ljubljana, Univerzitetna knjižnica Maribor, Univerzitetna knjižnica Univerze Nova Gorica i Univerzitetna knjižnica Univerze na Primorskem), no na mrežnim stranicama nijedne od njih nije moguće pronaći smjernice, odnosno neki dokument takva sadržaja. Jednake rezultate pretrage daje istraživanje mrežnih stranica sveučilišnih knjižnica u Bosni i Hercegovini (Nacionalna i univerzitetska biblioteka Bosne i Hercegovine, Narodna i univerzitetska biblioteka Republike Srpske, Biblioteka Univerziteta u Tuzli, Univerzitetska biblioteka Univerziteta „Džemal Bijedić“ u Mostaru, Sveučilišna knjižnica Sveučilišta u Mostaru, Kantonalna i univerzitetska biblioteka Bihać i Univerzitetska biblioteka Univerziteta u Zenici), Srbiji (Univerzitetska biblioteka „Svetozar Markovićc, Univerzitetska knjižnica Univerziteta u Kragujevcu i Centralna biblioteka Univerziteta Novi Sad) i Crnoj Gori (Centralna univerzitetska biblioteka i Biblioteka Univerziteta Donja Gorica). Stoga je pretraga ciljano proširena na zemlje za koje je iz literature poznato da njeguju praksu izrade smjernica za izgradnju fonda. U Europi se to najviše odnosi na sveučilišne knjižnice na području Velike Britanije i Irske, a izvan Europe na SAD. Pretraga mrežnih stranica sveučilišnih knjižnica u SAD-u pokazala je vrlo velik broj javno objavljenih smjernica za izgradnju i upravljanje fondom, što je u skladu s američkom knjižničnom praksom. Pritom napominjemo da se smjernice nalaze na stranicama knjižnica pod različitim nazivima: collection developement giudelines, collection

\footnotetext{
20 Gradska i sveučilišna knjižnica Osijek, Smjernice za nabavu. [citirano: 2017-01-16]. Dostupno na: http://www.gskos.unios.hr/ descape/files/Smjernice\%20za\%20nabavu\%20GISKO.pdf.

21 Nacionalna i sveučilišna knjižnica u Zagrebu. Smjernice za izgradnju zbirke Croatica. [citirano: 2017-01-19]. http://www.nsk.hr/wp-content/uploads/2016/06/Smjernice-za-izgradnju-zbirke-Croatica-3.pdf.
} 
developement policy, collection development and management policy i sl., no sadržajno odgovaraju smjernicama za izgradnju fonda.

Kao jedan od kvalitetnih primjera smjernica može se izdvojiti Library Collection Development Policy na SOAS University of London. ${ }^{22}$ Spomenuti dokument sadrži cijeli niz elemenata koji su ranije navedeni kao potrebni i koje i SVKRI može uzeti kao polazište: izjave o misiji sveučilišta i same knjižnice, svrhu smjernica s aspekta zaposlenika i korisničke populacije, navode o suradnji s drugim knjižnicama i udruženjima, pristup drugim knjižnicama, odnosno njihovim fondovima, podatke o financiranju, kriterije za selekciju građe, politiku s darovima, kriterije za nabavu serijskih publikacija, uputu o prijedlozima za nabavu i kriterije za njihovo odobravanje, politiku nabave elektroničkih izvora, upute za institucijski repozitorij, kriterije za pročišćavanje fonda i otpis građe. Radi se o sveobuhvatnom dokumentu koji je na stranicama knjižnice prezentiran kao prohodni obrazac koji u svom početnom dijelu sadrži samo kostur i kratka objašnjenja pojedinih kategorija, što ga čini privlačnim korisniku koji sam izabire dijelove dokumenta o kojima želi znati više.

\subsection{Prethodno iskustvo}

Iako smjernice za središnju knjižnicu SVKRI još nije izradio u cijelosti, u knjižnici postoji iskustvo s izradom i implementacijom smjernica za izgradnju fonda. Od 1. ožujka 2011. u okviru Kampusa na Trsatu u Rijeci djeluje podružnica Sveučilišne knjižnice. Ona obavlja knjižničnu djelatnost za četiri sveučilišna odjela i Učiteljski fakultet, koji nemaju knjižnice u svojem sastavu. Specifičnost je navedene podružnice to što ona organizacijski nije podružnica u tradicionalnom smislu, odnosno ne radi se samo o zadovoljavanju potreba dislociranih korisnika, već je ustrojena po načelima visokoškolske knjižnice pri fakultetima. ${ }^{23}$ Prije početka rada Podružnice Kampus izrađene su i javno objavljene Smjernice za izgradnju fonda Podružnice Kampus. ${ }^{24}$ Smjernice su izrađene unutar SVKRI-a i sadržavaju sljedeće elemente: definiciju ciljne korisničke populacije, opis zbirke Podružnice, kriterije za nabavu prinova, navod o vrstama građe koje se nabavljaju, načine nabave po pojedinim zbirkama, metode vrednovanja zbirki, način financiranja izgradnje fonda, politiku postupanja s darovima te navod o godišnjem uređenju fonda i reviziji. Radi se dakle o cjelovitu dokumentu koji pruža djelat-

\footnotetext{
22 SOAS University of London. Library collection development policy. [citirano: 2017-01-19]. ${ }^{D}$ stupno na: https://www.soas.ac.uk/library/about/collectiondevpolicy/.

23 Lazzarich, L. Uloga podružnice sveučilišne knjižnice u visokoškolskom sustavu. // Vjesnik bibliotekara Hrvatske 55, 3-4(2013), str. 72.

24 Podružnica Kampus Sveučilišne knjižnice Rijeka. Smjernice za izgradnju fonda. [citirano: 2017-01-16]. Dostupno na: http://kampus.svkri.uniri.hr/index.php/vodic-za-korisnike/18-vodic-za-korisnike/26.
} 
nicima, korisnicima, financijerima i ostaloj zainteresiranoj javnosti jasnu sliku o tome što se, kako, kada i pod kojim uvjetima nabavlja i pohranjuje, odnosno kako se zbirka vrednuje.

\subsection{Temeljne postavke smjernica SVKRI-a}

SVKRI u izradi smjernica polazi od nekoliko temeljnih postavki, odnosno zahtjeva:

- preustroj fizičkih zbirki s ciljem formiranja posudbenog fonda primjerenog ciljnoj korisničkoj populaciji Knjižnice

- izrada kriterija za odabir građe koja se uvrštava u fond, pri čemu treba osigurati jednaku zastupljenost sadržaja iz svih područja koja se izučavaju na Sveučilištu

- uspostavljanje kriterija za nabavu elektroničkih izvora s naglaskom na sadržaju u otvorenom pristupu

- uspostavljanje kriterija za digitalizaciju građe iz fonda knjižnice

- uspostavljanje kriterija za pročišćavanje fonda i otpis građe

- preregistracija kulturnog dobra

- definiranje sveobuhvatne politike prema darovima.

Navedeni zahtjevi proizašli su iz potrebe da se fond prilagodi misiji knjižnice, ali i problema koji se pojavljuju u poslovanju pri pokušajima integriranja elektroničke i druge građe u knjižnično poslovanje. Kroz nove smjernice definirat će se dvije temeljne zbirke: Nacionalna zbirka i Opći fond. Iz smjernica će korisniku biti jasno kakva se građa nalazi u kojoj zbirci, odnosno podzbirci te koji su uvjeti korištenja, odnosno pristupa građi. Nacionalna zbirka imat će tri podzbirke: Opći dio Nacionalne zbirke, Zavičajnu zbirku Adriatica, Sveučilišnu zbirku i Zbirku Disertationes Universitatis Fluminensis (DUF).

Zbirka DUF sadrži doktorske radove obranjene na Sveučilištu u Rijeci. Sveučilišna zbirka okupljat će građu čiji su autori djelatnici Sveučilišta u Rijeci, koju su izdale sastavnice Sveučilišta, odnosno čiji se sadržaj odnosi na Sveučilište. Zavičajna zbirka Adriatica obuhvaćat će, kao i do sada, građu čiji su autori i/ili izdavači s područja zavičaja (područje Kvarnera, kvarnerski otoci, Gorski kotar i dio Like), odnosno koja o zavičaju govori. Dio građe koji je trenutno dio zbirke Adriatica, a odgovara kriterijima za uvrštavanje u Sveučilišnu zbirku, bit će u nju i preseljen. Iz zavičajne zbirke bit će izlučena i u Nacionalnu zbirku, odnosno Opći fond premještena građa koja se odnosi na Istru, odnosno čiji su autori i/ili izdavači s područja Istre, s obzirom na to da je revizijom kriterija za izgradnju zbirke Adriatica odlučeno da područje Istre ne pripada pod pojam zavičaja. Opći dio Nacionalne zbirke okupljat će preostalu građu hrvatskih autora, građu izdanu u 
Hrvatskoj, odnosno onu koja o Hrvatskoj govori. U navedene zbirke uvrštavat će se po jedan primjerak građe i u načelu će se građa iz tih zbirki korisnicima davati na uvid u prostoru Knjižnice, ali neće biti moguća njena posudba izvan Knjižnice.

Posudbi izvan Knjižnice bit će namijenjena građa u Općem fondu. U tu će se zbirku uvrštavati dodatni primjerci građe iz Nacionalne zbirke i njezinih podzbirki te sva građa koja se nabavlja u svrhu zadovoljavanja potreba korisnika, primarno studenata i znanstveno-nastavnog osoblja Sveučilišta u Rijeci.

U smjernice će se ugraditi kriteriji za nabavu građe kupnjom, s naglaskom na potrebi da se osigura primjerena zastupljenost sadržaja iz svih područja koja se izučavaju na Sveučilištu. Pritom, zbog činjenice da unutar Sveučilišta djeluju i fakultetske knjižnice, mora biti uzet u obzir i raspoloživ broj naslova, odnosno odobren broj pristupa sadržaju koje su osigurale fakultetske knjižnice. Definiranje kriterija za kupnju građe iznimno je važno s obzirom na vrlo ograničena sredstva kojima knjižnice raspolažu u tu svrhu. SVKRI pored vlastitih sredstava, koja su nedostatna, ima na raspolaganju i sredstva za nabavu literature koja osigurava osnivač. No ona su strogo namjenska i moraju se koristiti za nabavu studentske ispitne i seminarske literature. Upravo je zato važno predvidjeti jasne kriterije (građa koja se nalazi na popisima ispitne i seminarske literature na fakultetima, građa koju fakultetske knjižnice nemaju u dovoljnom broju primjeraka ili ju nemaju uopće, građa koju studenti i znanstveno-nastavno osoblje identificiraju kao potrebnu u njihovu radu) kako bi se namjenskim sredstvima nabavilo građu koja odgovara zahtjevima osnivača, a potom, u granicama mogućnosti, vlastitim sredstvima nabavljati preostalu građu koja zadovoljava potrebe korisnika.

Nabava elektroničkih izvora u suvremenoj je hibridnoj knjižnici nužnost. Dijelom je ta nužnost u Hrvatskoj uvjetovana zakonskim propisima u području znanosti i obrazovanja, a dijelom potrebom samih znanstvenika, istraživača i studenata da imaju osiguran pristup najnovijim sadržajima u polju svoga djelovanja. Osiguravanje pristupa tim izvorima iznimno je skupo i u pravilu same knjižnice nisu u mogućnosti plaćati licencije za svjetske znanstvene baze podataka. Pored toga, pristup svjetskim znanstvenim bazama podataka u Republici Hrvatskoj osigurava se i na nacionalnoj razini za sve knjižnice u sustavu znanosti kroz projekt Povećanje pristupa elektroničkim izvorima znanstvenog i stručnih izvora financiranja (e-Izvori). ${ }^{25} \mathrm{U}$ smjernice je stoga potrebno ugraditi napomenu o provođenju godišnje analize baza podataka koje se nabavljaju na nacionalnoj razini. U skladu s time i dostupnim financijskim sredstvima Knjižnice, u smjernicama se ugrađuju temeljni kriteriji za nabavu komercijalnih elektroničkih izvora. Najčešće se ti kriteriji odnose na sadržaj, odnosno predmet, cijenu, jezik ${ }^{26}$ i sl. koji u ovom slučaju

25 Projekt e-Izvori. [citirano: 2017-04-07]. Dostupno na: http://baze.nsk.hr/projekt-e-izvori/.

26 Johnson, P. Developing and managing electronic collections: the essentials. Chicago : Americal Library Associatin, 2013. Str. 22. 
moraju biti usklađeni ne samo s misijom i potrebama SVKRI-a već i s misijom i potrebama zajednice na Sveučilištu u Rijeci, a da se pritom ne poklapaju s već nabavljenim na nacionalnoj razini.

Pitanje otvorenog pristupa također je jedna od vrlo aktualnih tema. Brojne su publikacije u otvorenom pristupu koje je moguće uvrstiti u knjižnični katalog, odnosno učiniti korisniku dostupnima kroz alate poput discovery servisa. ${ }^{27}$ No omogućavanjem pristupa takvoj građi, bilo kroz knjižnični katalog ili kroz discovery servis, ona postaje dio knjižničnog fonda i stoga mora odgovarati određenim kriterijima. Kada se radi o građi u otvorenom pristupu, sličnost sadržaja koji su na raspolaganju sa sadržajima koji su dio kurikuluma sveučilišnih programa ne može biti jedini kriterij. Kao što knjižnica ne treba u svoj materijalni fond uvrštavati svu građu s ciljem da je ima što više, tako to ne treba činiti ni s elektroničkom građom. Stoga će se u smjernice ugraditi i dodatni kriteriji poput zahtjeva da se radi o recenziranim publikacijama, pouzdanom izdavaču, kao i da je osigurana stabilna poveznica na sadržaj.

U elektroničkom obliku u fondu knjižnice nalazi se i digitalizirana građa. SVKRI digitalizaciju provodi u svrhu zaštite, poboljšanja dostupnosti, stvaranja nove ponude te upotpunjavanja fonda. U svim tim aktivnostima dužnost je Knjižnice držati se odredbi Zakona o autorskom pravu i srodnim pravima. Kako Hrvatska, kao i druge europske zemlje, ima prilično restriktivan zakon u području autorskih prava, oblikovanje kriterija za digitalizaciju je otežano. U svrhu zaštite knjižnica može digitalizirati građu, no taj digitalizirani primjerak nije dopušteno dalje distribuirati korisnicima bez pribavljanja dozvole nositelja autorskog prava ukoliko autorska prava nad konkretnim primjerkom još uvijek postoje. Digitalizacijom u svrhu zaštite knjižnica osigurava sadržaj publikacije za slučaj uništenja materijalnog primjerka. U smjernice se ugrađuju željeni kriteriji za formiranje zbirke digitalizirane građe (starost i stanje materijalnog primjerka, zahtjevi korisnika, značaj za istraživanje i zajednicu, postojanje digitaliziranog primjerka u drugim ustanovama). Kako u Hrvatskoj ne postoji središnji registar koji bi okupljao podatke o svim digitalizacijskim projektima, odnosno svim zbirkama digitalizirane građe, moguće je da se ista građa digitalizira više puta, što predstavlja gubitak vremena i financijskih sredstava koja su u to uložena. Stoga je važno temeljito istražiti postoji li digitalizirani primjerak građe u Hrvatskoj, ali i u zemljama u okruženju. Dio građe, kao rezultat povijesnih kretanja na ovom području, imaju knjižnice u Italiji, Austriji ili Mađarskoj, te je kroz suradnju moguće dobiti ili primjerak digitalizirane građe ili pristup istom.

Ipak, u smjernice se mora ugraditi napomena da je nužno pridržavati se važećih zakonskih odredbi iz područja autorskih prava. Uvrštavanjem takve formulacije

27 Objedinjeni pretraživač koji jednim upitom pretražuje sve dostupne izvore informacija knjižnični katalog, pretplaćene baze podataka, ali i odabrane mrežne izvore informacija u slobodnom pristupu. 
otvara se mogućnost da pri eventualnoj promjeni zakonodavne regulative (npr. usvajanjem Marakeškog ugovora ${ }^{28}$ ) ne bude potrebno u tom dijelu odmah revidirati i smjernice.

Jednom kada je knjižnični fond izgrađen, potrebno ga je uvijek iznova procjenjivati, što podrazumijeva postupke revizije, izlučivanja i otpisa građe, odnosno pročišćavanje fonda. Periodična revizija knjižničnog fonda propisana je odredbama Pravilnika o reviziji i otpisu, pa u smjernice moraju biti ugrađene odredbe koje odgovaraju propisima iz navedenog pravilnika. No pročišćavanje fonda aktivnost je u upravljanju fondom koja se mora provoditi kontinuirano kako bi fond ostao primjeren korisniku i kako bi podupirao misiju knjižnice. Stoga se u smjernice ugrađuju kriteriji tog postupka: izlučivanje iz fonda i otpis zastarjele, prekobrojne i nepovratno oštećene građe, odnosno izdvajanje i pohrana rjeđe tražene građe u zajednička spremišta - depozitorije. Pritom se kriteriji odnose na dio fonda koji je moguće otpisati, dakle isključena je građa koja je zaštićeno kulturno dobro, odnosno koja je pristigla kao obvezni primjerak Republike Hrvatske.

Velik dio knjižničnog fonda SVKRI-a zaštićeno je kulturno dobro. Zaštićenim kulturnim dobrom proglašena je sva građa koja je bila u vlasništvu knjižnice zaključno s 15. 5. 1969. To je rezultiralo iznimno velikim brojem zaštićenih svezaka (ukupno oko 230000 ), no nije sva zaštićena građa u toj kategoriji iz stvarne potrebe. Tako postoji niz naslova koje knjižnica posjeduje i u velikom broju primjeraka (neke naslove i u deset primjeraka), ali ih ne može dati korisnicima na korištenje izvan Knjižnice, ne može ih otpisati kao prekobrojne iako to jesu niti oni mogu biti predmetom razmjene s drugim knjižnicama, čime se gubi jedna od mogućnosti nabave građe koja baštinskom dijelu fonda nedostaje. Smjernicama će se predvidjeti broj primjeraka građe koja će se čuvati, kao i uvjeti njezina korištenja. Kroz smjernice i preustroj fizičkih zbirki planira se dati temelj za postupak preregistracije kulturnog dobra. Postupak preregistracije zbirki podrazumijeva obradu sve građe u baštinskom dijelu fonda i stoga se predviđa da će taj postupak potrajati. No njegov će rezultat biti uređenje baštinskog fonda, čime će biti olakšano njegovo istraživanje, a samim time i povećana njegova vrijednost kao resursa Knjižnice.

Knjižnica se u svakodnevnom radu susreće s darovima koji se uobičajeno dijele na željene i neželjene. Željeni darovi odgovaraju nabavnoj politici knjižnice,

28 Marakeški ugovor o olakšavanju pristupa objavljenim djelima za osobne koje su slijepe, imaju oštećenje vida ili druge poteškoće u korištenju tiskanim djelima omogućit će ovlaštenim ustanovama (kojima pripadaju i knjižnice) adaptaciju i distribuciju tiskanih djela s ciljem postizanja potpune pristupačnosti objavljene tiskane građe slijepima i slabovidnima. Vidi: Uredba (EU) 2017/1563 Europskog parlamenta i Vijeća od 13. rujna 2017. o prekograničnoj razmjeni između Unije i trećih zemalja primjeraka u dostupnom formatu određenih djela i drugih predmeta zaštite koji su zaštićeni autorskim pravom i srodnim pravima u korist osoba koje su slijepe, koje imaju oštećenje vida ili imaju drugih poteškoća u korištenju tiskanim materijalima. // Službeni list Europske unije 60, L 242/1(2017). [citirano: 2017-10-27]. Dostupno na: http://eur-lex.europa.eu/legal-content/HR/TXT/?uri=uriserv:OJ.L_.2017.242.01.0001.01.HRV\&toc=OJ:L:2017:242:TOC. 
svojim sadržajem podupiru misiju knjižnice, odnosno uklapaju se u kriterije za izgradnju fonda i knjižnica svojim djelovanjem nastoji privući takve darove. Neželjeni darovi mnogo su veći problem i u praksi su prilično česti. Tako se knjižnici daruje građa koje se pojedinci ili institucije jednostavno žele riješiti, najčešće zbog potrebe za oslobađanjem fizičkog prostora. Takva je građa često zastarjela i ne odgovara kriterijima za uvrštavanje u knjižnični fond. Stoga će se u smjernice ugraditi jasna politika knjižnice prema darovima i definirati uvjeti i način njihova prihvaćanja, odnosno kriteriji na temelju kojih knjižnica dar može odbiti. Temeljni kriterij za prihvaćanje darova ponuđenih knjižnici jest njihova primjerenost fondu. Darovana građa svojim sadržajem mora odgovarati istim kriterijima kao i građa koju knjižnica kupuje. S druge strane, kako ova knjižnica posjeduje velik baštinski fond, kao dar će svakako prihvatiti i onu građu koja taj fond može dodatno obogatiti.

U javno objavljenim smjernicama američkih i europskih knjižnica, uz dijelove koji se odnose na politiku prema darovima, najčešće su dostupni i obrasci i upute za potencijalne darovatelje, što smatramo dobrom praksom koja će biti primijenjena i u smjernicama SVKRI-a. Takvi obrasci tražit će osnovne podatke o darovatelju (ime i prezime te kontakt-podaci) i građi koju želi darovati knjižnici (naslov, autor, izdavač, godina izdanja, odnosno naslov serijske publikacije, godište, godina i brojevi te napomena o stanju u kojem se građa nalazi). Obrasci će, zajedno s uputama za potencijalne darovatelje i kontakt-podacima ovlaštenih osoba u Knjižnici, biti dostupni na mrežnim stranicama Knjižnice, ali i u tiskanom obliku u prostoru Knjižnice. Smjernicama jasno izražena politika prema darovima predstavljat će pomoć djelatnicima u komuniciranju s potencijalnim darovateljima, dok će darovateljima dati jasnu sliku o tome kakvu građu knjižnični fond SVKRI-a treba.

\section{Zaključak}

Izgradnjom knjižničnog fonda knjižnice se bave otkad i same postoje. Temeljni je to resurs na kojem se grade sve usluge koje knjižnica pruža, odnosno koji omogućava knjižnici ostvariti ciljeve izražene kroz vlastitu misiju. Velike promjene u području informacijsko-komunikacijske tehnologije koje je čovjek ugradio u svakodnevni život promijenile su očekivanja i potrebe korisnika, očekivanja osnivača, a time i poslovanje knjižnice.

Proces izgradnje knjižničnog fonda postao je još kompleksniji u odnosu na ono što je bio u tradicionalnoj knjižnici. Suvremena hibridna knjižnica uvrštava u svoj fond građu u izvorno digitalnom obliku, mrežno dostupnu građu, a poželjno je i da sama formira zbirke digitalizirane građe iz vlastitog materijalnog fonda kako bi povećala dostupnost i olakšala pristup. U takvoj složenoj i promjenjivoj okolini 
postojanje smjernica za izgradnju fonda, koje služe kao okvir i vodič u izgradnji fonda, postaje potreba.

No kao što je sam fond postao složeniji zbog pojave novih vrsta i oblika građe te nove tehnologije, tako je i izrada temeljnog dokumenta poput smjernica postala izazovnija. Izradi smjernica nužno je pristupiti ozbiljno, analizom misije knjižnice i ciljeva koji su pred nju postavljeni te proučavanjem zakonodavstva koje u bilo kojem dijelu utječe na poslovanje knjižnice. Izrađuju se slijedeći određeni teorijski okvir, ali prije svega moraju biti primjerene sustavu i jasne njegovim korisnicima te drugim zainteresiranim akterima.

Sveučilišna knjižnica Rijeka započela je proces izrade smjernica za izgradnju fonda s ciljem da postojeći fond prilagodi vlastitoj misiji te da u smjernicama stvori okvir za razvoj fonda u budućnosti, uzimajući pritom u obzir promjenjivo okruženje u kojem danas djeluje. Knjižnica polazi od misije da bude potpora u znanstvenom, obrazovnom, istraživačkom i umjetničkom radu Sveučilišta u Rijeci. Stoga se uz pomoć smjernica namjerava provesti cjelovit preustroj materijalnih zbirki knjižnice, s temeljnim ciljem stvaranja posudbenog fonda koji će odgovarati potrebama ciljne korisničke populacije.

No smjernice se neće zadržati na materijalnom fondu knjižnice, već će sadržavati i kriterije za uvrštavanje $u$ fond građe $u$ izvorno digitalnom obliku, odnosno mrežno dostupne građe. Istaknut će kakvoj sve građi, odnosno sadržaju koji nije njezino vlasništvo Knjižnica osigurava pristup putem knjižničnog kataloga i/ili discovery servisa, bilo da se radi o komercijalnim sadržajima ili sadržaju koji je dostupan u otvorenom pristupu.

Naposljetku, smjernice će se, jednom kada budu usvojene, javno objaviti na mrežnim stranicama knjižnice i putem društvenih mreža koje knjižnica koristi, a s ciljem da se približe postojećim i potencijalnim korisnicima kako bi imali jasnu predodžbu o tome što mogu očekivati od fonda Sveučilišne knjižnice Rijeka.

\section{LITERATURA}

Darovi za zbirke : smjernice za knjižnice. Upute za izradbu smjernica za izgradnju knjižnične zbirke primjenom modela Conspectus.; Međunarodna posudba i dostava dokumenata : načela i smjernice za postupanje ; Model nacionalnog pravilnika za međuknjižničnu posudbu. Zagreb : Hrvatsko knjižničarsko društvo, 2010.

Gradska i sveučilišna knjižnica Osijek. Smjernice za nabavu. Dostupno na: http://www. gskos.unios.hr/ descape/files/Smjernice\%20za\%20nabavu\%20GISKO.pdf [citirano 2017-01-16]. 
Guy, R. F. Developing the hybrid library : progress to date in the National Library of Scotland. // The Electronic Library 18, 1(2000), 40-50. DOI: https://doi. org/10.1108/02640470010320452

Hebrang Grgić, I. Dar kao način izgradnje zbirki u hrvatskim narodnim knjižnicama. // Vjesnik bibliotekara Hrvatske 54, 3(2011), 95-106.

Horava, T; M. Levine-Clark. Current trends in collection development practicies and policies. // Collection Building 35, 4(2016), 97-102. DOI: https://doi.org/10.1108/ CB-09-2016-0025

Johnson, P. Developing and managing electronic collections: the essentials. Chicago : American Library Associatin, 2013.

Johnson, P. Fundamentals of collection development and management. 2nd ed. Chicago : American Library Association, 2009.

Kodrič-Dačić, E. Uvod v izgradnjo knjižničnih zbirk. // Knjižnica 51, 1 (2007). [citirano: 2017-01-31]. Dostupno na: http://revija-knjiznica.zbds-zveza.si/Izvodi/K0701/ kodric1.pdf

Krajna, T. Nabava knjižnične građe u visokoškolskim knjižnicama. // Vjesnik bibliotekara hrvatske 54, 3(2011), 21-42.

Lazzarich, L. Uloga podružnice sveučilišne knjižnice u visokoškolskom sustavu. // Vjesnik bibliotekara Hrvatske 55, 3-4(2013), 69-78.

Majstorović, Z. Razvoj Zbirki u sveučilišnom knjižničnom sustavu primjenom Conspectus modela: doktorska disertacija. Zagreb : Z. Majstorović, 2009.

Majstorović, Z; K. Ivić. Izgradnja zbirki u sveučilišnom knjižničnom sustavu: model. // Vjesnik bibliotekara Hrvatske 54, 3(2011), 43-67.

Nacionalna i sveučilišna knjižnica u Zagrebu. Smjernice za izgradnju zbirke Croatica. [citirano: 2017-01-19]. Dostupno na: http://www.nsk.hr/wp-content/uploads/2016/06/Smjernice-za-izgradnju-zbirke-Croatica-3.pdf.

Podružnica Kampus Sveučilišne knjižnice Rijeka, Smjernice za izgradnju fonda. [citirano: 2017-01-16]. Dostupno na: http://kampus.svkri.uniri.hr/index.php/vodic-za-korisnike/18-vodic-za-korisnike/26.

Prijedlog Zakona o knjižnicama i knjižničnoj djelatnosti. Srpanj 2014. [citirano: 201702-01]. Dostupno na: http://www.hkdrustvo.hr/clanovi/alib/datoteke/20140905-Prijedlog_zakona_o_knjiznicama_i_knjiznicnoj_djelatnosti_za_strucnu_raspravu(1). doc.

Projekt e-Izvori. [citirano: 2017-04-07]. Dostupno na: http://baze.nsk.hr/projekt-e-izvori/.

Sanchez Vignau, B. S.; G. Meneses. Collection development policies in university libraries : a space for reflection. // Collection Building 24, 1(2005), 35-45. DOI: https:// doi.org/10.1108/01604950510576119. 
SOAS University of London. Library collection development policy. [citirano: 2017 01-19]. Dostupno na: https://www.soas.ac.uk/library/about/collectiondevpolicy/.

Sveučilišna knjižnica Rijeka. Povijest. [citirano: 2017-01-15]. Dostupno na: http:// www.svkri.uniri.hr/index.php/o-nama/povijest.

Sveučilišna knjižnica Rijeka. Vizija i misija. [citirano: 2017-01-17]. Dostupno na: http:// www.svkri.uniri.hr/index.php/o-nama/vizija-i-misija.

Uredba (EU) 2017/1563 Europskog parlamenta i Vijeća od 13. rujna 2017. o prekograničnoj razmjeni između Unije i trećih zemalja primjeraka u dostupnom formatu određenih djela i drugih predmeta zaštite koji su zaštićeni autorskim pravom i srodnim pravima u korist osoba koje su slijepe, koje imaju oštećenje vida ili imaju drugih poteškoća u korištenju tiskanim materijalima. // Službeni list Europske unije 60, L242/1(2017). [citirano: 2017-10-27]. Dostupno na: http://eur-lex.europa.eu/legal-content/HR/TXT/?uri=uriserv:OJ.L_.2017.242.01.0001.01.HRV\&to$\mathrm{c}=\mathrm{OJ}: \mathrm{L}: 2017: 242:$ TOC.

Živković, D. Knjižnice na putu od poslanja do strategije: osvrt na hrvatske prilike. // Vjesnik bibliotekara Hrvatske 58, 1-2(2015), 1-14. 